\title{
INVESTIGATION OF THE INFLUENCE OF NANOPARTICLES OF METALS ON FERMENTTATION OF WORT OF HIGH CONCENTRATIONS
}

Svetlana Kovalchuk

Department of Biotechnology of fermentation and winemaking products National University of Food Technology

68 Volodymyrska str., Kyiv, Ukraine, 01601

sofi55508@ukr.net

Peter Shiyan

Department of Biotechnology of fermentation and winemaking products National University of Food Technology

68 Volodymyrska str., Kyiv, Ukraine, 01601

chiyan@nuft.edu.ua

Tatiana Mudrak

Department of Biotechnology of fermentation and winemaking products National University of Food Technology

68 Volodymyrska str., Kyiv, Ukraine, 01601

mudrak_t_o@ukr.net

Anatoly Kuts

Department of Biotechnology of fermentation and winemaking products National University of Food Technology 68 Volodymyrska str., Kyiv, Ukraine, 01601 anatolykuts@ukr.net

Roman Kyrylenko

Department of Biotechnology of fermentation and winemaking products National University of Food Technology 68 Volodymyrska str., Kyiv, Ukraine, 01601 nuftkrg@ukr.net

\footnotetext{
Abstract

There was theoretically grounded and experimentally proved the expedience of enriching high-concentrated wort of the starch-containing raw material with such additional source of mineral nutrition for yeast cells as nanoparticles of metals.

There was studied the influence of nanoparticles of metals on hydrolysis of biopolymers of the raw material and biosynthesis of organic compounds at wort fermentation. It was experimentally established, that the most positive influence of biosynthetic properties of yeast cells is realized by zinc and magnesium. At using zinc and magnesium, yeast biomass and alcohol content in mashes increase.

Best chemical-technological indices of mashes were received at adding nanoparticles of zinc and magnesium at the stage of batch dilution.

There was experimentally studied the synthesis of volatile organic admixtures in marsh distillates depending on point of adding nanoparticles of metals.

Keywords: yeast, wort, alcohol marsh, nanoparticles of metals, marsh distillate.

\section{Introduction}

Fermentation of wort of high concentrations is a promising and attractive research direction and has the important practical value. However, fermentation of wort of high concentrations conditions the increase of the specific output of alcohol, decrease of energy consumption, decrease production wastes. But the increase of fermentation temperature and also increase of ethanol concen- 
tration in marshes results in extreme conditions for yeast life activity. It is known, that yeast cells are demanding to the cultivation environment and need essentially more mineral substances under stress conditions. Zinc, in its turn, positively influences stress-tolerance of cells, activate enzymes of a yeast cell, fermentation activity [1]. Magnesium positively influences budding of yeast cells [2]. The microelement of iron is necessary for the synthesis of a series of respiration enzymes. In little amounts it stimulates budding of cells [3]. Cuprum, necessary for respiration enzymes, increases fermentation activity of yeast cells. For improving physiological condition of industrial strains of Saccharomyces cerevisiae yeast, mineral nutrition is important. It can essentially influence the process of alcohol wort bioconversion. Not only the qualitative and quantitative composition, but "bioaccessibility" of metals in fermented substrates is important. It is known, that many metals influence yeast productivity that is why more attention must be paid to mineral components in wort. At the same time physiologically adapted yeast cultures are able to increase general indices of alcohol marsh [4-7].

The influence of macro- and microelements of physiological processes is explained by the fact that they are included in accessory substances: respiratory pigments, vitamins, hormones, enzymes that take part in regulation of life activity processes [8-10]. The great importance in alcohol production is inherent to yeast biological activity. Their physiological condition influences the speed of processes and composition of fermentation products. For today the study of the influence of nanomaterials and their use in food industry, especially in alcohol one, is a promising scientific direction [11-13].

The idea of using nanoparticles for fermentation of wort of high concentrations is based on the fact that substances in the nanoform have properties, different from ones of substances in the macrodispersed form. From the microbiological point of view, approaches, based on nanotechnologies, may be used for increasing the quality and safety of food products [14].

Especially, the high specific surface of nanomaterials leads to the fact that surface phenomena begin to prevail in processes of their interaction with macromolecules and biological objects [15-19]. It is resulted in the fact that even small concentrations of nanoparticles can essentially influence yeast cells.

The aim of the work was to study the influence of nanoparticles of metals on hydrolysis of biopolymers of the raw material and biosynthesis of organic compounds at high-concentrated wort fermentation. And also their influence on the synthesis of volatile organic admixtures in marsh distillates depending on point of metal nanoparticles introduction. It allows to improve chemo-technological indices of alcohol marshes at fermentation of wort of high concentrations.

\section{Materials and Methods}

The grist of corn grains with dispersity $100 \%$ of pass through the sieve with the orifices diameter $1 \mathrm{~mm}$ was used for the study. For producing and fermenting industrial yeast, wort with the concentration $28 \%$ of DS was used. Wort was fermented by the osmophilic, thermo-tolerant strain of Saccharomyces cerevisiae yeast Y - 16 .

Amyloidity of output grain was determined by Evers' method [20]. Grain humidity - by Chizhova's method and drying to the constant mass [20].

The granulometric composition of the grist of grain was determined by the method of sowing on metal and kapron sieves [20]. The concentration of dry substances - using the sugar meter and on the refractometer [20].

Wort from corn with the concentration $28 \%$ of DS was used for cultivating industrial yeast in laboratory conditions.

Wort preparation was realized by the low-temperature scheme of soft boiling at the temperature $85-92{ }^{\circ} \mathrm{C}$ using concentrated enzyme preparations of $\alpha$-amylase with the duration 3 hours. The diluted mass was cooled to the temperature $50-55{ }^{\circ} \mathrm{C}$ and sugared by glucoamylase during 0,5 hours. After sugaring, wort was pasteurized at the temperature $80^{\circ} \mathrm{C}$ during $20 \mathrm{~min}$., cooled to $50{ }^{\circ} \mathrm{C}$ and acidulated by sulphuric acid to the acidity $0,5-0,6$ degrees. Yeast cultivation was realized at the temperature $30-32{ }^{\circ} \mathrm{C}$. For diluting and sugaring of batches, there were used enzymatic preparations, made by "Danisko", Belgium: as $\alpha$-amylase - Amilex 4T, glucoamylase - Diazim TGA (Fig. 1). 


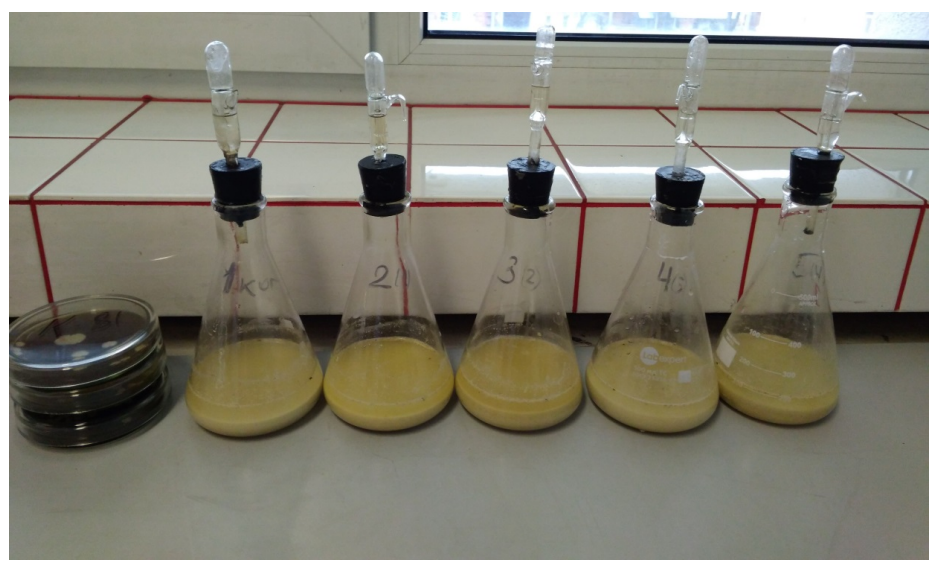

Fig. 1. Preparation of samples for wort fermentation in laboratory condition

The physiological condition of yeast cells was determined by coloration of a yeast cell by Lugol's solution, the content of dead cells - by blue methylene, the amount of budding yeast and their accumulation - in Goryav's chamber.

In laboratory conditions pure cultures of studied yeast from the shoal were resown in a testtube with sterile wort with the concentration $9-10 \%$ of DS and fermented during 24 hours at the temperature $30^{\circ} \mathrm{C}$. After that the content of the test-tube was sterilely transferred in a flask that contains $200 \mathrm{ml}$ of sterile wort, and fermented during 24 hours, marsh was centrifuged, residual was washed by the physiological solution and used for fermenting wort.

The total number of yeast cells in $1 \mathrm{~cm}^{3}$ was determined by the method of direct calculation in Goryav's chamber.

Nanoparticles of aqueous dispersions were transferred from the Problem scientific-research laboratory of the National university of food technologies (Ukraine), kept by the method of volumetric electric-spark dispersion of current-conductive metals in liquid.

The studies of electrophoretic mobility and distribution of particles by sizes in the colloid system were realized by the method of photocorrelation spectroscopy LCS on the laser spectrometer Zeta Sizer Nano (Malvern, Great Britain) (Fig. 2, c) with the electric system of measurement of $\zeta$-potential Universal Dipcell (ZEN1002) and cell - Disposable polystyrene (DTS0012).

In laboratory conditions wort was fermented by the method of "fermenting sample" in conic tubes with sulphuric acid locks in the thermostat at different temperatures $30-35{ }^{\circ} \mathrm{C}$ Fig. 1 . The dynamics of the carbon dioxide emission was controlled by the weight method [20].

$\mathrm{pH}$ in mature marsh was determined by the electrometric method, ethanol content - by the pycnometric method, soluble and alcohol-soluble carbohydrates, insoluble starch and dextrins - by the photoelectrocolorimetric method with the antrhron reagent [20] Fig. 2, b.

The composition of volatile admixtures in marsh distillates was determined by the gas chromatographic method on the gas chromatograph Crystal-2000M CSC SCB "Chromatech", Joshkar-Ola, Russia, Fig. 2, $\boldsymbol{a}$.

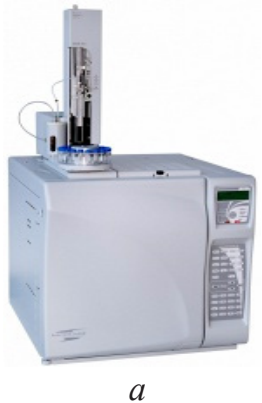

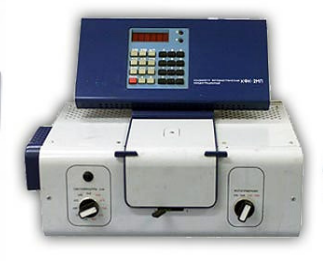

$b$

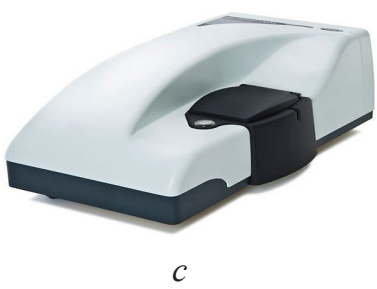

Fig. 2. Equipment: $a$ - Crystal-2000M, $b$ - Photocolorimeter CPC-2MP, $c$ - Laser spectrometer Zeta Sizer Nano 


\section{Results and Discussion}

The studies of the influence of $\mathrm{Mg}, \mathrm{Fe}, \mathrm{Cu}, \mathrm{Zn}$ nanoparticles on the process of fermentation of wort of high concentrations of the starch raw material were realized in the work.

Wort was prepared of corn, the grist dispersity was $100 \%$ of pass through the sieve with the orifices diameter $1 \mathrm{~mm}$. The wort concentration was $28 \%$ of DR. The concentration of sowing yeast $-30 \mathrm{mln} / \mathrm{cm}^{3}$. Carbamide in the calculation of $800 \mathrm{~g} / \mathrm{m}^{3}$ was added as nitrogen nutrition. The concentration of nanoparticles of metals was $1,2 \mathrm{mcg} / \mathrm{cm}^{3}$.

Nanoparticles of metals were introduced at the stage of batch dilution and wort fermentation.

As it was shown by research results, samples with $\mathrm{Mg}$, despite the stage of its introduction, demonstrated better chemo-technological indices of marsh compared with the control. The content of alcohol in marshes increased by 1,2-1,5\% (Table 1).

Table 1

Influence of nanoparticles of metals on fermentation of sources of high concentrations

\begin{tabular}{|c|c|c|c|c|c|c|c|c|c|c|c|}
\hline \multirow{2}{*}{ No. } & \multirow{2}{*}{$\begin{array}{l}\text { Point of } \\
\text { nanoparti- } \\
\text { cles intro- } \\
\text { duction }\end{array}$} & \multirow{2}{*}{$\begin{array}{l}\text { Metal } \\
\text { name }\end{array}$} & \multirow{2}{*}{$\sum_{\mathrm{g} / 200 \mathrm{~cm}^{3}} \mathrm{CO}_{2}$} & \multirow{2}{*}{ pH } & \multicolumn{4}{|c|}{$\begin{array}{l}\text { Content of non-fermented } \\
\text { carbohydrates, } \mathrm{g} / 100 \mathrm{~cm}^{3}\end{array}$} & \multirow{2}{*}{$\begin{array}{l}\text { Alcohol } \\
\text { content, } \\
\text { \% об. }\end{array}$} & \multirow{2}{*}{$\begin{array}{c}\text { Number of } \\
\text { yeast cells, } \\
\text { mln } / \mathrm{cm}^{3}\end{array}$} & \multirow{2}{*}{$\begin{array}{c}\% \text { of } \\
\text { dead cells }\end{array}$} \\
\hline & & & & & $\begin{array}{l}\text { Soluble } \\
\text { carbohy- } \\
\text { dratess }\end{array}$ & $\begin{array}{c}\text { Insoluble } \\
\text { carbohy- } \\
\text { drates }\end{array}$ & Dextrins & $\begin{array}{l}\text { Alcohol- } \\
\text { soluble car- } \\
\text { bohydrates }\end{array}$ & & & \\
\hline 1 & \multirow{5}{*}{$\begin{array}{l}\text { Before } \\
\text { dilution }\end{array}$} & $\mathrm{Mg}$ & 21,74 & 4,58 & 0,46 & 0,04 & 0,17 & 0,25 & 13,46 & 221 & 9 \\
\hline 2 & & $\mathrm{Fe}$ & 21,30 & 4,55 & 0,58 & 0,08 & 0,28 & 0,30 & 13,32 & 214 & 8 \\
\hline 3 & & $\mathrm{Cu}$ & 21,34 & 4,60 & 0,52 & 0,09 & 0,24 & 0,28 & 13,38 & 218 & 10 \\
\hline 4 & & $\mathrm{Zn}$ & 21,20 & 4,50 & 0,63 & 0,08 & 0,31 & 0,32 & 13,30 & 230 & 7 \\
\hline 5 & & All metals & 21,67 & 4,53 & 0,49 & 0,05 & 0,23 & 0,26 & 13,40 & 219 & 8 \\
\hline 6 & \multirow{5}{*}{$\begin{array}{c}\text { Before } \\
\text { fermentation }\end{array}$} & $\mathrm{Mg}$ & 21,54 & 4,53 & 0,50 & 0,09 & 0,24 & 0,26 & 13,41 & 225 & 9 \\
\hline 7 & & $\mathrm{Fe}$ & 21,32 & 4,52 & 0,58 & 0,10 & 0,26 & 0,32 & 13,31 & 218 & 10 \\
\hline 8 & & $\mathrm{Cu}$ & 21,29 & 4,54 & 0,63 & 0,10 & 0,34 & 0,29 & 13,30 & 220 & 10 \\
\hline 9 & & $\mathrm{Zn}$ & 21,30 & 4,52 & 0,57 & 0,09 & 0,25 & 0,32 & 13,30 & 258 & 8 \\
\hline 10 & & All metals & 21,41 & 4,54 & 0,55 & 0,09 & 0,28 & 0,27 & 13,39 & 232 & 9 \\
\hline 11 & Cont 1 & & 20,93 & 4,51 & 0,68 & 0,2 & 0,34 & 0,32 & 13,27 & 218 & 13 \\
\hline
\end{tabular}

But despite a zone of introduction of nanoparticles of metals and their mixture, marsh indices were better compared with the control sample.

Introduction of nanoparticles of metals at the stage of dilution favored not only the increase of fermenting activity of yeast, but had a positive influence of dilution and sugaring of a batch that may be connected with activation and stabilization of enzymatic preparations. It is proved by the decrease of the content of insoluble starch in marshes by 10-35\% compared with the control.

Thus, the use of nanoparticles of metals has a positive influence of the process of yeast fermentation. There were realized the studies of the synthesis of volatile organic admixtures in marsh distillates depending on point of metal nanoparticles introduction (at the stage of batch dilution and wort fermentation). According to the data (Table 2), it was established, that at adding metal nanoparticles, acetaldehyde concentration decreases comparing with the control sample.

Metal nanoparticles introduction was most effective at the stage of batch dilution, and the concentration of this component depended on a metal. The least amount of acetaldehyde was accumulated at introducing all studied components and was $110,9 \mathrm{mg} / \mathrm{dm}^{3}$. The same concentration was observed in the synthesis of complex asters.

The analysis of the synthesis of fusel alcohols in samples with adding nanoparticles demonstrated that the amount of N-propanol increases by 53,4-80\% depending on type of metal nanopar- 
ticles and zone of their introduction. Their concentration was practically close to the control by the sum of high alcohols. Only in samples, where metal nanoparticles were introduced at the dilution stage, their concentration decreased by $17,5-18 \%$. The content of methanol in all studied samples was at the level of the control sample.

Table 2

Synthesis of volatile organic admixtures in mature marshes depending on metal nanoparticles introduction

\begin{tabular}{|c|c|c|c|c|c|c|c|c|c|c|c|c|}
\hline \multirow{3}{*}{ No. } & \multirow{3}{*}{$\begin{array}{c}\text { Components of } \\
\text { marsh distillates, } \\
\text { mg/dm }\end{array}$} & \multirow{3}{*}{ Control } & \multicolumn{10}{|c|}{ Point of nanoparticles introduction } \\
\hline & & & \multicolumn{5}{|c|}{ Dilution } & \multicolumn{5}{|c|}{ Fermentation } \\
\hline & & & Mg & $\mathbf{C u}$ & $\mathbf{F e}$ & Zn & $\begin{array}{c}\text { All } \\
\text { metals }\end{array}$ & Mg & $\mathbf{C u}$ & $\mathrm{Fe}$ & Zn & $\begin{array}{c}\text { All } \\
\text { metals }\end{array}$ \\
\hline 1 & Acetaldehyde & 150,87 & 130,2 & 129,1 & 131,3 & 125,2 & 110,9 & 134,2 & 135,1 & 134,7 & 132,34 & 159,9 \\
\hline 2 & Methyacetate & 1,925 & 6,478 & 5,840 & 7,39 & 6,95 & 8,280 & 8,914 & 8,520 & 9,19 & 8,95 & 8,31 \\
\hline 3 & Ethylacetate & 222,4 & 212,8 & 243,9 & 216,7 & 217,8 & 198,6 & 237,0 & 241,5 & 259,5 & 248,32 & 239,4 \\
\hline 4 & $\begin{array}{l}\text { Sum of complex } \\
\text { esters }\end{array}$ & 224,63 & 233,6 & 249,74 & 224,09 & 224,75 & 216,88 & 245,91 & 250,02 & 268,69 & 257,27 & 247,5 \\
\hline 5 & N-butanol & 12,534 & 13,48 & 13,25 & 15,38 & 14,18 & 13,38 & 15,63 & 15,45 & 16,44 & 15,98 & 15,84 \\
\hline 6 & N-propanol & 513,542 & 787,0 & 820,3 & 910,1 & 859,0 & 804,7 & 944,0 & 928,14 & 910,5 & 912,13 & 939,1 \\
\hline 7 & Isobutyl alcohol & 397,328 & 338,4 & 340,4 & 350,8 & 348,14 & 423,6 & 404,7 & 425,7 & 456,0 & 465,11 & 385,1 \\
\hline 8 & Isoamyl alcohol & 1737,8 & 1209,0 & 1190,1 & 916,82 & 1253,0 & 1373,0 & 1397,0 & 1328,0 & 1563,0 & 1483,3 & 1332,0 \\
\hline 9 & $\begin{array}{l}\text { Sum of fusel } \\
\text { alcohols }\end{array}$ & 2660,23 & 2347,88 & 2364,0 & 2193,1 & 2474,3 & 2614,6 & 2761,3 & 2697,3 & 2945,9 & 2876,5 & 2672,0 \\
\hline 10 & Acids & 37,63 & 36,63 & 35,81 & 33,444 & 31,85 & 35,26 & 36,11 & 35,24 & 32,34 & 33,42 & 35,71 \\
\hline 11 & $\begin{array}{l}\text { Methyl alcohol, } \\
\text { об. \% }\end{array}$ & 0,002 & 0,003 & 0,0028 & 0,0029 & 0,003 & 0,003 & 0,0031 & 0,0031 & 0,0027 & 0,0028 & 0,003 \\
\hline
\end{tabular}

The studies on determination of concentrations of volatile organic compounds in marsh distillates allow to make a conclusion that their synthesis depends on type of metal nanoparticles and also on zone of their introduction into the technological process.

\section{Conclusions}

There was studied the influence of metal nanoparticles on bioconversion of wort and synthesis of organic compounds. It was established, that the most positive influence on wort fermentation was realized by zinc and magnesium. At their use the concentration of yeast cells in marshes increased in 1,3-2,0 times compared with the control, at that the alcohol content in marshes increased by $1,2-1,5 \%$.

Best chemical-technological indices of mashes were received at adding nanoparticles of zinc and magnesium at the stage of batch dilution.

Introduction of nanoparticles of metals at the stage of dilution favored not only the increase of fermenting activity of yeast, but had a positive influence of dilution and sugaring of a batch that may be connected with activation and stabilization of enzymatic preparations. It is proved by the decrease of the content of insoluble starch in marshes by 10-35\% compared with the control.

Thus, metal nanoparticles introduction has the positive influence on the process of yeast-generation and fermentation of high wort concentrations.

The shortcoming of the studies is a difficultness of using nanoparticles of aqueous dispersions in industrial conditions, because these systems are unstable during a long time. 
The further development of this study may be in elaborating the technology of fermentation of wort with DS concentration higher than $28 \%$, and also using other forms of nutrition for yeast cells.

\section{References}

[1] Sehati, S., Clement, M. H. S., Martins, J., Xu, L., Longo, V. D., Valentine, J. S., Gralla, E. B. (2011). Metabolic alterations in yeast lacking copper-zinc superoxide dismutase. Free Radical Biology and Medicine, 50 (11), 1591-1598. doi: 10.1016/j.freeradbiomed.2011.03.004

[2] Suizu, T., Tsutsumi, H., Kawado, A., Murata, K., Imayasu, S. (1994). On the importance of calcium and magnesium ions in yeast sporulation. Journal of Fermentation and Bioengineering, 77 (3), 274-276. doi: 10.1016/0922-338x(94)90233-x

[3] Pas, M., Piskur, B., Sustaric, M., Raspor, P. (2007). Iron enriched yeast biomass - A promising mineral feed supplement. Bioresource Technology, 98 (8), 1622-1628. doi: 10.1016/j.biortech.2006.06.002

[4] Walker, G. M. (2004). Metals in Yeast Fermentation Processes. Advances in Applied Microbiology. Elsevier, 197-229. doi:10.1016/s0065-2164(04)54008-x

[5] Rimareva, L. V., Overchko, M. B., Serba, E. M., Agashicheva, K. L., Ignatova, N. I. (2011). Fermentation of concentrated cereal wort using the osmophilic race of alcoholic yeast Saccharomyces cerevisiae 1039. Production of alcohol and alcoholic beverages, 3, 10-127.

[6] Kosiv, R., Kharandiuk, T., Polyuzhyn, L., Palianytsia, L. et al. (2016). Optimization of Main Fermentation of High-Gravity Wort. Chemistry \& Chemical Technology, 10 (3), 349-353. doi: 10.23939/ chcht10.03.349

[7] Oliinichuk, S. T., Tkachenko, L. V., Protsan, N. V., Kozachenko, S. V. (2006). Influence of metal ions on the activity of concentrated enzyme preparations. Production of alcohol and alcoholic beverages, $2,80-869$.

[8] Khalilova, E. A., Islamamgomedova, E. A., Kotenko, S. T. (2011). Some features of the amino acid exchange in yeast metabolism S. cerevisiae Y-503 on a nutrient medium with geothermal water of the phenolic class. Production of alcohol and alcoholic beverages, 2, 9-12.

[9] Khalilova, E. A., Islamagomedova, E. A., Kotenko, S. T. (2011). Elementary composition of S. cerevisiae Y-503 strain, cultivated on different nutrient media. Production of alcohol and alcoholic beverages, 4, 19-2012.

[10] Udeh, H. O., Kgatla, T. E., Jideani, A. I. O. (2014). Effect of Mineral Ion Addition on Yeast Performance during Very High Gravity Wort Fermentation. International Journal of Biological, Biomolecular, Agricultural, Food and Biotechnological Engineering, 8 (11), 1208-1216.

[11] He, X., Hwang, H.-M. (2016). Nanotechnology in food science: Functionality, applicability, and safety assessment. Journal of Food and Drug Analysis, 24 (4), 671-681. doi: 10.1016/j.jfda.2016.06.001

[12] Hamad, A. F., Han, J.-H., Kim, B.-C., Rather, I. A. (2017). The intertwine of nanotechnology with the food industry. Saudi Journal of Biological Sciences. doi: 10.1016/j.sjbs.2017.09.004

[13] Gallocchio, F., Belluco, S., Ricci, A. (2015). Nanotechnology and Food: Brief Overview of the Current Scenario. Procedia Food Science, 5, 85-88. doi: 10.1016/j.profoo.2015.09.022

[14] Ranadheera, C. S., Prasanna, P. H. P., Vidanarachchi, J. K., McConchie, R., Naumovski, N., Mellor, D. (2017). Nanotechnology in Microbial Food Safety. Nanotechnology Applications in Food. Elsevier, 245-265. doi: 10.1016/b978-0-12-811942-6.00012-1

[15] He, X., Hwang, H.-M. (2016). Nanotechnology in food science: Functionality, applicability, and safety assessment. Journal of Food and Drug Analysis, 24 (4), 671-681. doi: 10.1016/j.jfda.2016.06.001

[16] Ram, P., Vivek, K., Kumar, S. P. (2014). Nanotechnology in sustainable agriculture: Present concerns and future aspects. African Journal of Biotechnology, 13 (6), 705-713. doi: 10.5897/ajbx2013.13554

[17] Sekhon, B. (2014). Nanotechnology in agri-food production: an overview. Nanotechnology, Science and Applications, 7, 31-53. doi: 10.2147/nsa.s39406

[18] Kumari, A., Yadav, S. K. (2014). Nanotechnology in Agri-Food Sector. Critical Reviews in Food Science and Nutrition, 54 (8), 975-984. doi: 10.1080/10408398.2011.621095

[19] Rashidi, L., Khosravi-Darani, K. (2011). The Applications of Nanotechnology in Food Industry. Critical Reviews in Food Science and Nutrition, 51 (8), 723-730. doi: 10.1080/10408391003785417

[20] Polygalin, G. V. (1999). Techno-chemical control of alcohol and liquor-vodka production. Moscow: Kolos, 334. 